Q

11

P62

1889

Physical \&

Applied Sei.

Serials.

\title{
SUPPLEMENTAL REGISTER
}

OF

WRITTEN COMMUNICATIONS

PUBLISFED

I. THE

Transactions and Proceedings OF TIE

AMERICAN PHILOSOPHICAL SOCIETY, 1881-1889.

COMPILED BY

HENRY PHILLIPS, JR., ONE OF THE SECRETARIES OF THE SOCIETY. 



\title{
Supplemental Register
}

OF

\author{
WRITTEN COMMUNICATIONS
}

PUBLISHED

IN THE

\section{TRANSACTIONS AND PROCEEDINGS}

OF THE

American Philosophical Society.

$1881-1889$.

COMPILED BY

HENRY PHILLIPS, Jr.,

ONE OF THE SECRETARIES OF THE SOCIETY.

PHILADELPHIA :

Press of MacCalla d Co., 237-9 Dock Street. 1 sis9. 

A SUPPIFMIEINAI REGISTER

oF

WRITTEN COMMUNICATIONS

PUBLISHED IN

THE TRANSACTIONS

OF THE

\section{AMERICAN PHILOSOPHICAL SOCIETY.}

Compiled by Henry Phillips, Jr., ONe of the Secretaries of the Society.

TRANSACTIONS. [NEW SERIES.]

VOL. XVI.

ABBOTT, H. DeC. S.-Chemical Study of the Yucca Angustifolia .............................. XVI. 254

COPE, E. D.-Systematic Catalogue of the Species of Permian Vertebrata of North America.............. XVI. 285

Intercentrum of the Terrestrial Vertebrata.......... XVI. 243

Shoulder Girdle and Extremities of Eryops ......... XVI. 362

Synopsis of the Vertebrate Fauna of the Puerco Series. XVI. 298

McCAULEY, E. Y.--Egyptian Dictionary ........... XVI. i 


\title{
A SUPPLEMENTAL REGISTER
}

OF

\section{WRITTEN COMMUNICATIONS}

PUBLISHED IN

\author{
TEE PIROCEEDINGS
}

OF THE

\section{AMERICAN PHILOSOPHICAL SOCIETY,}

\author{
Frow
}

No. 115 to 128.

Vols. XXI-XXIV. 18s1-1889.

Complled hy Henty l'Hullips, Jr.,

One of the Secretaries of the Society.

АВВОтT, H. C. DeS.-An Analysis of the Bark Fouquieira splendens.............................. XXI. 701

On the Occurrence of a Series of New Crystalline Compounds in Higher Plants.................. XXV. 124

AGNEW, D. Hayes.-Biographical Sketch of the late Elias P. Beadle ........................... XXII. 227

ALGER, Abby L.-A Collection of Words and Phrases taken from the Passamaquoddy Tongue............... XXII. 240 ALLEN, Harrison.-Obituary Notice of Dr. Albert H. Smith. XXIII. 606 On a case of Human Congenital Malformation ...... XXI. 413 ASHBURNER, C. A.-Notes on the Natural Briclge of Virginia ..................................... 699 Remarks on the Recent Publications of the Second Geological Survey of Pennsylvania.............. XXII. 86 On Kintzes' Firedamp Indicator . .............. XXI. 283 BARKER, George F.-On the Henry Draper Memorial Photographs of Stellar Spectra................. XXIV. 166 
BLASIUS, William. -The Remarkable Sun Glows in the Falls of 1883 and $1884 \ldots \ldots \ldots \ldots \ldots \ldots \ldots$ XX............. 213

The Signal Service Bureau, Its Methods and Results.. XXIV. 179

BOAS, Franz.-Notes on the Ethnology of Britislı Columbia....................................... 422

BRANNER, John C.-The Course and Growth of the FibroVascular Bundles in Palms....................

The Glaciation of Parts of Wyoming and Lackawanna Valleys............................... XxiII. 337 BRINTON, Daniel G.-A Grammar of the Cakchiquel Lan-

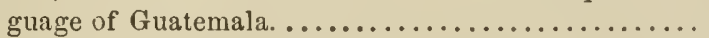

On the Language and Ethnologic Position of the Xinca Indians of Guatemala.................. XxII. 89

The Lineal Measures of the Semi-Civilized Nations of Mexico and Central America.................. XXII. 194

The Philosophic Grammar of American Languages, as set forth by Wilhelm von Humboldt ............ XXII. 306

The Verb in American Languages............... XXII. 332

On Polysynthesis and Incorporation as Characteristics of American Languages .................... XXIII. 48

Notes on the Mangue, an Extinct Dialect formerly spoken in Nicaragud......................XXIII. 238

On the Ikonomatic Method of Phonetic Writing, with Special Reference to American Archeology..........XXIII. 503

The Conception of Love in some American Langnages, XXIII. 546 Critical Remarks on the Editions of Diego de Landa's Writings ............................ XXIV. 1 Were the Toltecs an Historic Nationality? ......... XXIV. 229 On an Ancient Human Fontprint from Nicaragua ..... XXIV. 437 The Language of Palæolithic Man ............... XXV. 212 Obituary Notice of Philip H. Law... ............ XXV. 225 On the so-called Alaguilac Language of Guatemala ... XXIV. 366 BROCKWAY, E. B.-Thermometrical Observations in

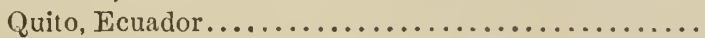
XXI. 676 CARSON, Hampton L.-Biographical Sketch of Generıl A.

A. Humphreys........................ XXII. 48 CARTER, Oscar S.-Detection of Adulterations in Oil.... XXII. 296 CHASE, Pliny E.-Photodynamic Notes.............XXI. 120, 590 Experiment in Weather Forecast ............... XII. 207 The Chase-Maxwell Ratio..................... XxII. 375 Thermo-electro-photo-baric Unit................ XXII. 377 CLAYPOLE, E. W.-Perry County Faults........... XXI. 218

A Relic of the Native Flora of Pennsylvania, surviving

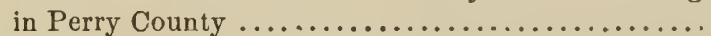
Equivalent of the New York Portage in Perry County, Pennsylvania

XXI. 226

XXI. 230 
CLAYPOLE, E. W.-Genus Rensselaria in the Hamilton Group, Perry County, Pennsylvania.............

A Large Crustacean from the Catskill Group of Penn-

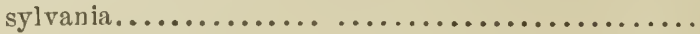

On the Clinton and other Shales composing the Fifth Group in the First Survey of Pennsylvania ........ XXI. 492

Organic Variation Indefinite not Definite in Direction. . XXIV. 113 COPE, Edward D.-Letter from Loup Fork............. XXI. 216

On the Distribution of the Loup Fork Formation in New

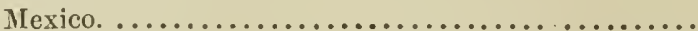

Second Addition to the Knowledge of the Puerco Epoch On the Trituberculate Type of Tooth in the Mammalia. Synopsis of the Species of Oreodontidæ.............. Structure of the Skuli in the Elasmobranch Genus Didymodus ............................... XXI. 572

Extinct Nammalia of the Valley of Mexico......... XXII. 1

Structure of the Feet in the Extinct Artiodactyla of North America......................... XXII. 21

Fifth Contribution to the Knowledge of the Fauna of the Permian Formation of Texas and Indian Territory .................................... 28

A Contribution to the Herpetology of Mexico......... XXII. 379

A Second Continuation of Researches among the Batrachia of the Coal Measures of Ohio................ XXII. 405

Twelfth Contribution to the Herpetology of Tropical America............................. XxII. 167

Thirteenth Contribution to the Herpetology of Tropical America.............................. XXIII. 271

Contribution to the Vertebrate Palæontology of Brazil. XXIII. 1

Catalog of the Species of Batrachians and Reptiles contained in a collection made at Pebas, Upper Amazon, by John Hanxwell ................... XxIII. 94

Report on the Coal Deposits near Zacualtipan, in the State of Hidalgo, Mexico .................. XXIII. 146

Structure of the Brain and Auditory Apparatus of a Theromorphous Reptile of the Permian Epoch...... XXIII. 234 On the Species of Iguaninæ...................XIII. 261 On Two New Species of Threc-toed Horses from the Upper Miocene, with Notes on the Fauna of the Ticholeptus Beds ........................... XIII. 357 On the Structure and Affinities of the Amphiumidæ ... XXIII. 442 Analytical Table of the Genera of Snakes ........... XXIII. 479 Synonymic List of the North American Species of Bufo and Rana.* * ................................. 514 Synopsis of the Batrachia and Reptilia obtained in the Province of Mato Grosso, Brazil...............XXIV. 44 
COPE, Edward D.-Classification and Pliylogeny of the Artiodactyla ............................. XXIV. 377

Contribution to the History of the Vertebrata of the Trias of North America.................... XxIV. 209

On the Dicotylinæ of the John Day Miocene of North America.................................. 62

On the Mechanical Origin of the Dentition of the Amblypoda ................................... 80

CRANE, T. F.-Mediæval Sermon Books and Stories...... XXI. 49 CURWEN, John.-Obituary Notice of Dr. Thomas S. Kirkbride........................................ 217

DA COSTA, J. M.-Biographical Sketch of Samuel D. Gross................................ 78

DAVIS, Wm. Morris.-Conversion of Chlorine into Hydrochloric Acid ............................

DAY, Frank MI.-Microscopic Examination of Timber, with regard to its Strength................... XXI. 333

DU BOIS, Patterson.-Obituary Notice of James C. Booth. XXV. 204 DUDLEY, Thomas H.-Is there Reciprocity in Trade and Consumption of Manufactured Commodities? . .... XXIII. 526 DUGÉE, Alfredo.-Le Rhinocheilus Antonii ............. XXIII. 290 Deux espéces Nouvalles des Ophidiens de Mexique... XXV. 181 FRAZER, Persifor.-Trap Dykes in the Archrean Rocks of Southeastern Pennsylvania...................

A Convenient Device to be applied to the Hand Compass................................................ 216

Resume of the Work of the International Congress of

Geologists, held at Berlin, Sept. 28 to Oct. 3, 1885... XXIII. 259

Sketch of the Geology of Iork County, Pennsylvania. XXIII. 391

Composite Photography applied to Handwriting....... XXIII. 433

Report on the Geology of Eastern Cuba ............ XXV. 123

GARMAN, Samuel B.-Reptiles and Batrachians of Grand Cayman.................................... 273

West Indian Reptiles in the Museum of Comparative Zoölogy at Cambridge, Mass................. XXIV. 278 GARRETT, Philip C.-Obituary Notice of Pliny E. Chase. XXIV. 287 GATSCHET, Albert S.-On the Beothuk Indians........ XXII. 408 XXIII. 411

The Aruba Language and the Papiamento Jargon ..... XXII. 299 GENTH, F. A.-Herderite...................... XXI. 691 On the Vanadates and Iodyrite from Lake Valley, Sierra County, N. MI ........................ XXII. 363

Contributions to Mineralogy, No.XXIV........... XXIII. 30

Contributions to Mineralogy, No. XXIX............ XXIV. 23 GILL, Theodore. - Notes on the Stromateidce........... XXI. 664 GRAFF, Frederick.-Obituary Notice of Strickland Kneass. XXI. 451 
GROTE, Aug. R.-Introduction to the Study of the North American Noctuidce....................... XXI. 134

HAGEN, J. G. -On the Reversion of Series........... XXI. 93

HALE, Horatio. - The Tutelo Tribe and Language........ XXI. 1

HA NCOCK, Joseph L.-Description of Datames Magna... XXV. 107

HAUPT, L. M.-Physical Phenomena of Harbor Entrances. XXV. 19

HOFFMAN, W. J.-Remarks on Indian Tribal Names.... XXIII. 204

Vocabulary of the Seelish Language.............. XXIII. 367

HORN, G. H.-Obituary Notice of Dr. John L. LeConte... XXI. 291

HOUSTON, Edwin J.-Synchronous Multiplex Telegraph. XXI. 326

Photography by a Lightning Flash...............XXIII. 257

On some Possible Methods for the Preparation of Gramo-

phone and Telephone Records ................ XXV. 144

HUNT, T. Sterry.-The Classification and Nomenclature of

Metalline Minerals........................ XXV. 170

JORD $A N$, Francis, Jr.-Aboriginal Pottery of the Middle

Atlantic States.............................. XXV. 104

KEYES, Charles R.-On the Attachment of Platyceras to

Palæocrinoids, and its Effects in Modifying the Form

of the Shell. ......................... XXV. 231

KING, C. W.-Epitaph of M. Verrius Flaccus ......... XXV. 55

KIRKWOOD, Daniel.-Zone of Asteroids and the Ring of



Limits of Stability of Nebulous Planets and the Conse-

quences Resulting from their Mutual Relations...... XXII. 104

The Comet of 1866 and the Meteors of November 14... XXII. 424

Relation of Aerolites to Shooting Stars.............XIV. 111

The Possible Existence of Fireballs and Meteorites in

the Stream of Bielids....................... XXIV. 436

Biela's Comet and the Large Meteors of Nov. 27-30... XXIV. 242

KENIG, George A.-Note on Cosalite, Alaskalite and

Beegerite ........................... XXII. 211

KRAUSS, Friedrich._Aus Bosnien und der Hercegovina.. XXIII. 87

Ibrahim Nukić.......................... XXV. 183

LAW, Philip H.-Obituary Notice of William S. Vaux.... XXII. 404

Observations on Gildas and the Uncertainties of Early

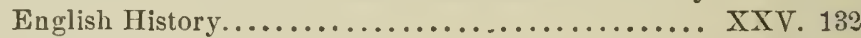

LESLEY, Joseph.-Growth in Ice.................. XXI. 217

LESI.EY, J. P.—Obituary Notice of Dr. John L. LeConte. . XXI. 291

Meaning of the "Set" Animal...................... 344, 455

Obituary Notice of James Macfarlane ............. XXIII. 287

On the Hebrew Word "ShDI" (Shaddai).......... XXIII. 303

Obituary Notice of F. V. Hayden............. XXV. 59

LESQUEREUX, Leo.-Obituary Notice of Oswald Heer. XXI. 286

LEWIS, H. Carvill. - A Great Trap-dyke across Southeast-

ern Penusylvania ....................... XXII. 438 
LILLEY, A. T.-Section of Chemung Rocks at LeRoy,

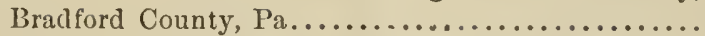

A Revision of the Section of Chẹmung Rock Exposed in the Gulf Brook Gorge at LeRoy, in Bradford County, Pennsylvania.......................... XxIII. 291

LOCKINGTON, W. N.-The Role of Parasitic Protophytes. XXI. 88

MANSFIELD, I. F.-Note of a Quartz Pebble Found in a Coal Bed ............................ XXI. 343

MCCAULEY, E. Y.-Inscription on a Mummy Case in Memorial Hall. ........................ XXI. 488

MEINERT, Fr.-MIyriapoda Musei Cantabrigensis, Mass., Part I, Chilopoda...................... XXIII. 161

MEYER, Otto.-Miocene Invertebrates from Virginia...... XXV. 135

MOONEY, James.-The Medical IIthology of Ireland.... XXIV. 136

Funeral Customs of Ireland................ XXV. 213

OLIVER, Charles A.-Subjective After-Colcr........... XXIII. 500

OSBORN, Henry F.-The Triassic Mammals Dromatherium and Microconodon......................... XXIV. 109

Preliminary Report on the Vertebrate Fossils of the Uinta Formation collected by the Princeton Expedition of 1886 , by H. R. Osborn and William B. Scott. XXIV. 126

PACKARD, A. S.-A Revision of the Lysiopetalidæ, a Family of the Chilognath Myriopoda with a Notice of

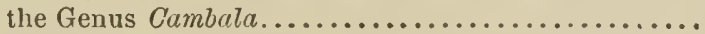

Discovery of the Thoracic Feet in a Carboniferous Phyllocariclian ............................. XXIII. $3 s_{0}$

On the Systematic Position of the Mallophaga........ XXIV. 264

Embryology of the Limulus Polyphemus, III......... XXII. 268

PEPPER, William.-Obituary Notice of Dr. John Forsyth

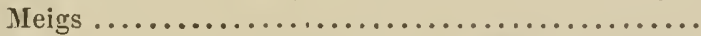

PHILLIPS, Henry, Jr.-Account of the More Important Public Collections of American Archæology in the

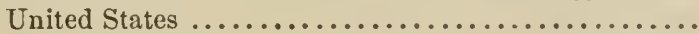

Note Respecting the Correct Name of the Last Letter of the English Alphabet.......................

On a Supposed Runic Inscription at Yarmouth, Nova



Notes on the Codex Ramirez, with a Translation of the

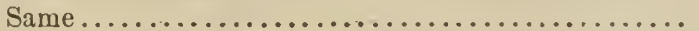

First Contribution to the Study of the Folk-lore of Philadelphia and its Vicinity.................. XXV. 159

RINK, H.-Recent Danish Explorations in Greenland, and their significance as to Arctic Science in General.... XXII. 280 ROBINSON, Moncure.-Obituary Notice of Henry Seybert. XXI. 241 ROTHROCK, J. T.-Biographical Memoir of the late Hon. Eli K. Price, LL.D..................... XXIII. $5 \tau_{2}$ 
RUSCHENBERGER, W. S. W.-Obituary Notice of Dr.

Robert Bridges....................... XXI. 427

A Sketch of the Life of Robert E. Rogers, M.D., LL.D.,

with Biographical Notices of his Father and Brothers. XXIII. 104

SCOTT, William B.-See OSBORN.

SELLERS, William.-Obituary Notice of George Whitney. XXIII. 383

SHARPLESS, Isaac.-Latitude of Haverford College Obser-

vatory............................. XXI. 78

SIMPSON, George.--Note of Drawings of Mr. Mansfield's

Eurypterids from Coal Shales............... XXI. 343

SMITH, Aubrey H.-Note on the Carex Miliaris.......... XXV. 320

SMITH, Edgar F.-Electrolysis of Lead Solutions. Determination of Boric Acid. Dihalogen Derivatives of Salicylic Acid. Barite..................... XXIV. 428

Action of Gas from $\mathrm{As}_{2} \mathrm{O}_{3}$ and $\mathrm{HNO}_{3}$ upon m-Oxyben.

zoic Acid............................. XXV. 194

STEVENSON, John J.-Geological Structure of Tazewell, Russell, Wise, Smyth and Washington Counties, Virginia....................................... 114

Notes Respecting Metamorphism............... XXII. 161

Geological Reconnoissance of Bland, Giles, Wythe and

Portions of Pulaski and Montgomery Counties of Vir-

ginia ............................ XXIV. 61

Notes on the Surface Geology of Southwest Virginia. . XXIV. 172

STOKES, Alfred.-New Hypotrichous Infusoria ......... XXIII. 21

New Fresh-water Infusoria...........XXIII. 562, XXIV. 244

STOLL, Otto, M.D.-Supplementary Remarks to the Grammar of the Cakcliquel Language of Guatemala..... XXII. 255

STOWELL, F. B.-The Facial Nerve in the Domestic Cat. XXIV. 8

The Trigeminus Nerve in the Domestic Cat.......... XXIII. 459

The Glosso-pharyngeal Nerve in the Domestic Cat ..... XXV. 89

The Accessory Nerve in the Domestic Cat ........... XXV. 94

The Hypoglossal Nerve in the Domestic Cat.......... XXV. 99

TAYLOR, Alfred B.-Octonary Numeration and its Appli. cation to a System of Weights and Measures ........ XXIV. 296

TAYLOR, W. Curtis.-Composite Photography.......... XXII. 360 THAYER, Rusşell.-Acrial Ships .................. XXI. 301

UHLER, P. R.-The Albirupean Formation, and its Nearest Relatives in Maryland. .................. XXV. 42

VAUX, Richard.-The Pennsylvania Prison System....... XXI. 651

Biographical Sketch of Henry M. Phillips........... XXII. 72

Obituary Notice of James R. Ludlow ............. XXIV. 19

WALL, J. Sutton.-Indian Picture Rocks in Fayette County,

Pennsylvania....................... Xxr. 687

WILLIAMS, Henry S.-On a Crinoid with Movable Spines. XXI. 81

WYCKOFF, A. B.--Use of Oil in Storms at Sea......... XxIII. 38:

WILSON, Jos. M.-Biographical Notice of Thomas U. Walter XXV. 323 



